\title{
Employee Retention in Institutions of Higher Learning: A Study of Some Selected University Colleges in Ghana
}

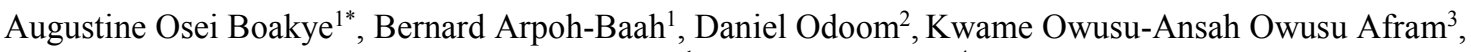 \\ Prince Addai ${ }^{1}$, David Agyemang ${ }^{4}$ \\ 1. Faculty of IT Business, Department of Management and Human Resources, Ghana Communication \\ Technology University, Ghana \\ 2. Department of Communication Studies, Ghana Institute of Journalism, Ghana \\ 3.Directorate of Human Resources and Organizational Development, Ghana Communication Technology \\ University, Ghana \\ 4.Department of Human Resource Management, Golden Star Wassa Ltd, Ghana \\ Email of corresponding author: aoboakye@gctu.edu.gh
}

\begin{abstract}
The study investigated the issue of employee retention across private tertiary institutions in Ghana with a focus on Senior Members of some selected university colleges in the Ashanti Region. The mixed-method approach was used in a descriptive survey design. In all, 111 respondents were selected from four university colleges using purposive and convenience sampling methods. Interview guide and questionnaire were relied upon in collecting data for the study, with frequencies, percentages, Kruskal-Wallis test and thematic analyses as analytical tools. The study observed that the expectations of Senior Members before accepting employment in the selected institutions include getting a high salary, better working conditions, more training opportunities, career development opportunities, a favourable working environment as well as obtaining some form of recognition and appreciation in the institutions. Again, several factors such as better remuneration, care and concern from employers, more training and development opportunities, better promotion system, conducive working environment, and increased employee engagement influenced retention of Senior Members in the institutions. However, no significant differences were observed in the views of Senior Members (academic and non-academic) of the selected institutions on the factors influencing employee retention. The study recommends that HR Units of the selected universities should effectively collaborate with the HRM experts of the universities to design fair and proper training and development programs to motivate employees to stay in the organizations.
\end{abstract}

Keywords: Employee retention, tertiary institutions, human resource management, Ghana

DOI: $10.7176 / \mathrm{JEP} / 13-5-06$

Publication date: February $28^{\text {th }} 2022$

\section{Introduction}

Human resources constitute a very critical ingredient for the attainment of organisational goals. According to Taher and Arifen (2000), with time the importance of the human factor in the realisation and attainment of organisational goals has increased considerably because of increasing competition and globalization of management. Robyn (2012) further states that the strength of an institution lies in its human capital and that it is therefore important to align human resource policies and procedures to attract and retain skilled employees. In this vein, organizations around the globe are vigorously competing for the best employees to achieve their organisational goals (Mahmud \& Idrish, 2011). Realizing the critical role that human resources play in organizations, employee retention remains very critical to the long-term health and success of business organizations (Guest, Michia, Conway \& Sheanan, 2003; Rombaut \& Guerry, 2019).

Research suggests that employers that fail to retain high-performing employees end up not only understaffed but also staffed with under-qualified personnel which can truncate their ability to have an urge over competitors (Mahmud and Idrish, 2011; Subramaniam, Choo \& Johari, 2019). In the views of Osei Boakye et al. (2021) and Malikarjunan (2006), managers of organizations are expected to motivate and retain high performing employees in an environment of increased uncertainties and global competition. Indeed, globalization and progressive technological changes leading to organisational downsizing and restructuring, have increased to need to pay attention to employee commitment and retention issues in organizations (Muah et al., 2021). According to Guthrie, as cited in Danso (2013), employees now highly believe in the diversification of their talents in the face of various dynamics in global businesses such as E-commerce-related companies. Danso (2013) adds that the greater business competition and economic realities have largely exposed the employee to limitless opportunities and options in the employment market. In essence, these limitless opportunities have caused some employees to terminate their job appointments in due course whilst others have seen retrenchment for various reasons. Nonetheless, the loss of skilled and talented employees has a significant effect on organisational performance and ultimate goal accomplishment. Beyond its effect on decline in productivity, this phenomenon leads to the cost of replacing an employee, the cost of orientation and training, and assimilating new talent, as well as the loss of investments in 
employees' development (Danso, 2013; Guest et al., 2003). In effect, employee retention hugely affects organisational performance and survival.

Particularly, in Ghana, employee retention has been a challenge (Danso, 2013). Dovlo (2002) found that many professions including the tertiary education sector in Ghana have suffered the problem of retention. While retention of well-qualified employees for both teaching and non-teaching sections remains a crucial requirement for the continued relevance of tertiary institutions (NAB, 2008), a key concern, especially the private ones, has been their inability to hire and retain well-qualified staff to actualize their visions and the overall aim of Ghana's educational sector. According to Kwegyir-Aggrey (2016), many private universities in Ghana have become vulnerable to losing their highly qualified academic and administrative staff to public universities and a few other private universities. Given the high turnover among the staff of private higher education institutions in Ghana, this study sought to explore and bring to the fore the factors influencing employee retention in some selected private university colleges in Kumasi, Ghana. Findings from this study are envisaged to assist human resource managers across similar tertiary institutions to be equipped with information that can strengthen their employee retentions initiatives and programmes.

\subsection{Research Objectives}

This study aimed to explore the factors influencing employee retention in selected private tertiary educational institutions in Kumasi, Ghana. To achieve this aim, the study specifically:

1. ascertained the expectations of Senior Members which influenced their decision to accept employment

2. explored the factors which would influence Senior Members' retention in the selected institutions.

3. examined whether a difference exists in the views of Senior Members (academic and non-academic) on the factors which would influence their retention in the institutions.

\subsection{Research Hypotheses}

H0: There is no significant difference in the views of Senior Members (academic and non-academic) on the factors which would influence their retention in the institutions.

H1: There is a significant difference in the views of Senior Members (academic and non-academic) on the factors which would influence their retention in the institutions.

\section{Overview of Literature}

\subsection{Conceptual review}

Employee retention is often regarded as the process in which the employees are encouraged to remain with the organization for the maximum period or until the completion of the project (Danso, 2013; Phillip \& Connell, 2002). Hughes and Rog (2008, p. 746) define retention as "ways of keeping talent within the organisation". According to Phillip and Connell (2002), employee retention is a way of managing and retaining talented employees using innovative retention programs. It is a vital element of an organization's approach to talent management. It is the implementation of integrated strategies or systems designed to increase workplace productivity by developing improved processes for attracting, developing, retaining, and utilizing people with the requisite skills and aptitude to meet current and future business needs (Lockwood, 2006).

The importance of putting in place measures to retain highly employees is well understood by the management of organizations. The payoff of focusing on employee retention, in terms of increased performance, productivity, employee morale and quality of work, a reduction in turnover and employee-related problems, is worth the investment of time and financial resources (Danso, 2013; Dhanpat et al., 2018; Naidoo, 2000). Also, retaining high-performing employees or the 'best professional talent' is of great significance to organizations as it eliminates the recruitment, selection and on-boarding costs that would otherwise be incurred in replacing them (Tymon, Stumpf and Smith 2011, 293). According to Toracco (2000), when an employee leaves, he takes with him valuable knowledge about the organization, customers, current projects and history sometimes to the organization's competitors. In support, Whitener (2001) opines that knowledge loss is the knowledge that is used to meet the needs and expectations of the customers.

Several human resource management (HRM) practices affect employee retention (Armstrong, 2007). For instance, Gopinath and Becker (2000) opined that a culture of open communication instils loyalty among employees and builds their trust. This is because information sharing helps to keep employees informed on key issues of which their opinions can be heard by management. Consequently, clear, responsive, open and two-way communication is key to the success of employee retention. In their views, Taylor and Cosenza (2002) argue that communicating the values of an organization effectively is crucial to its employees to increase their level of consent, participation and motivation; strengthen employee identification with the company; and build the trust of the employee in the organization. Armstrong (2007) asserts that information sharing keeps employees up-to-date on key issues and enables them to know that their opinions matter and that management is fully interested in their inputs. This means that every employee's view should be taken into consideration when formulating company 
policies. With a sense of ownership for an organization, employees may recognize their contribution in tough times and set out to work more effectively (Danso, 2013).

Again, remuneration and rewards play the biggest role in the process of employee retention. Rewards include a diverse range of formal and informal, financial and non-financial incentives given to individual employees, groups of employees or to an entire staff (Armstrong, 2007). They can be extrinsic or intrinsic. Rewards importantly affect job satisfaction because they fulfil the basic needs as well as help to attain the higher level of goals. An organization's reward system can affect the performance of the employee and their desire to remain employed (Bamberger \& Meshoulam, 2000). To ensure the retention of employees, pay needs to be transparent and salaries must be commensurate with the performance and effort of the employee (George, 2015). Additionally, recognizing their efforts or appreciating them is another powerful way to intrinsically motivate employees to stay. Recognizing or showing appreciation to employees for good work done goes a long way in motivating the employees. This makes employees feel indispensable for the organization. When employees see the team leader standing up for them, they will have one more reason to stay in the team (Greenburg, 2010).

Furthermore, Nohria, Groysberg and Lee (2008) contend that employees are motivated by jobs they consider as challenging since such jobs enable them to grow and learn. However, they become demoralized by jobs that seem to be monotonous or lead to a dead end. Consequently, the nature of one's job often affects their decision to stay in an organization. Giving extra responsibility to employees is another way to get them engaged with the organization. However, just giving the extra responsibility does not help (Robbins et al., 2007). Lawler (2008) and Osei Boakye et al., (2021) maintains that managers must spend time teaching their employees how to manage responsibilities given to them in order not to feel overburdened.

Moreover, the work environment is a key factor that affects employees' decision to stay with an organization (Bultmann, Huibers, van Amelsvoort, Kant, Kasl \& Swaen, 2005). Ramlall (2004) associates the work environment with an emphasis on physical aspects such as heavy lifts, noise, and exposure to toxic substances. In their views, Miller, Erickson and Yust (2001) state that employees gain from a positive work environment that provides a sense of belonging. Emotional and mental wellness is important to good retention and other indicators of business performance. Thus, employers need to consider employee health by providing an environment that is free from health hazards, offers a level of privacy, noise control and also takes into account the individual needs of each employee (Dhanpat et al. 2018; Levi, 2002).

According to Mandviwala (2011), the process of upgrading or promotion of employees in a traditional sense depended merely on past performances. Mandviwala (2011) further indicates that promoting employees today is not just a function of previous performances, but it also determines situations and willingness for future endeavours of employees. She adds that many organisations seem to use without-raise-promotions for employee retention, maximum productivity and optimum performance. These organizations usually do this either because of a salarybudget cut or to make an employee leave his job without making him or her realize the termination. If this practice is adopted for good reasons, according to Mandviwala, it may expand employees' skills along with eliminating a financial risk factor for the organization, improve the efficiency of employees, increase productivity and ensure employee retention.

Besides, employees' engagement in their work helps to motivate them. Engaging employees in the work they do motivates them to go an extra mile in the workplace which eventually helps in their retention in the organization. Employee engagement is seen as the extent to which employees value, enjoy and believe in their jobs and their employer (Beck, 2003). Achieving engagement is the result of a strong relationship between an employee and employer. In this way, employees are encouraged to have a passion for their work and identify the organization as more than a place to earn money (Danso, 2013; Kampt, 2006). Likewise, when management show care and concern for all the employees for them to feel secure at the workplace, it can incentivize them to stay.

Finally, the provision of timely, adequate and relevant training and development opportunities is necessary to retain current employees and for new employees to gain experience and knowledge of the products (Vinesh, 2014). According to Dhanpat et al. (2018), the provision of training must match the needs of employees and fill skills gaps, ensuring that workers remain competitive in the business environment. Training and development suggest to employees that the organization is investing in their development and growth, values them and is likely to provide a sense of job security (Kraimer et al., 2011). An advantage of this retention strategy is that it does not only reduce turnover but also enhances employees' performances and improve their motivation (Samuel \& Chipunza, 2009).

\subsection{Empirical Review}

Several studies have been done on staff retention within tertiary education institutions with various results. In a study conducted by Mercer (2003), it was found that staff positively recognition affects employee retention. The author further recommended that organisations should provide a great deal of personal and team recognition of achievements with alternative forms of acknowledgement such as memos, mentions in staff meetings, articles in the newspapers, dinners, and awards. In a similar study, Silbert (2005) observed that by having good relationships 
and open communication with supervisors, workers are likely to stay in an organization. Likewise, Gaiduk and Gaiduk (2009) review of previous studies revealed that employee intentions to remain with an organization are influenced by three major variables which are: employee personal characteristics such as gender, age, position level; the nature of an employee's current job; and adequate working arrangements including such aspects as the quality of current supervision, opportunities for promotion, available training, and quality of communication within the organization.

In another study involving 139 academics from Jordanian University, Al-Omari, Qablan and Khasawnneh (2009) established that job satisfaction and organizational commitment had a significant positive effect on the intention to stay among the academic staff. In a similar study at Makerere University, Amutuhaire (2010) found that remuneration influenced employee retention in the institution. A related study conducted by Mokoditoa (2011) in Limpopo University revealed that fringe benefits, promotion opportunities, job satisfaction and reward/compensation systems are the major determinants of retention of academics in the institution. In his research at the University of Cape Coast, Danso (2013) found that the best predictor of senior staff retention in the institution was total remuneration and rewards systems. Danso further found that promotion system, information sharing and training and development influence employee retention at the university.

In a study in Ghana by Kwaw (2015), it was established that factors including training and development, reward systems and promotion are vital in retaining staff at Cape Coast Polytechnic. Similarly, a study at Agogo College of Education by Odoom, Opoku and Ayipah (2016a) observed that promotion is a vital factor in employees' desire to stay in the institution. In another study, Odoom, Opoku and Ayipah (2016b) found that promotion is one critical factor that motivates employees to stay in organizations. Amegatsey (2017) revealed that Takoradi Polytechnic's inability to retain most of its pool of teaching staff as a result of poor remuneration, inadequate fringe benefits and poor welfare packages as compared to their counterparts in the universities. Similarly, Amegatsey, Odoom, Arpoh-Baah and Okyere (2018) found that promotion is crucial in employee retention especially in tertiary educational institutions in Ghana. The preceding literature review has demonstrated the instrumental role that the retention of employees can have on organizational health and success. In the same vein, the literature review has elucidated the variant factors which account for employee retention across the globe. It is however noteworthy that these studies were predominantly conducted in public tertiary institutions. It is therefore unclear if similar results are likely when the study is replicated in the private tertiary institutions. Moreover, the plethora of literature reviews on employee retention predominantly adopted the quantitative approach which frustrates our appreciation of the nuances and deeper meaning surrounding the factors identified. Accordingly, this present study will fill these literature gaps by conducting the study using the mixed method approach and a private tertiary institution.

\section{Research Methodology}

The study made use of the mixed methods approach. Specifically, the convergent parallel mixed methods design was adopted. Plano Clark and Creswell (2015) explained convergent parallel mixed methods design as a set of procedures that researchers use to concurrently collect both quantitative and qualitative data, analyze the two data sets separately, compare and/or synthesize the two sets of separate results, and make an overall interpretation as to the extent to which the separate results confirm and or complement each other. Since the study sought to investigate factors affecting retention at the selected university colleges, it is considered that findings from the interviews and the results from the questionnaire will help to make the work more reliable. The rationale for the convergent parallel design is that the two data forms have strengths and weaknesses, but if combined thoughtfully, then the strengths of one data form may be able to offset the weaknesses of the other form (Plano Clark \& Creswell, 2015).

The target population of the study consisted of all the senior members of the four selected university colleges namely, Garden City University College (GCUC), Spiritan University College (SUC), University College of Management Studies (UCMS) and Christ Apostolic University College (CAUC). The convenience and purposive sampling techniques were employed in drawing respondents for the study. The convenience sampling method was used on the basis that most of the teaching staff of the selected university colleges did not have offices in the institutions where the researchers could easily locate them, hence getting them was very difficult. Thus, the researchers selected 107 senior members made up of 85 teaching staff and 22 non-teaching staff. For the qualitative aspect, the purposive sampling method was used to select the Registrars of the university colleges. These officers play a critical role in HRM at the institutions. In essence, the four Registrars constituted the key informants of the study. In all, a total of 111 respondents were involved in the study.

The questionnaire and interview guide were the instruments for data collection. Given the mixed method nature of this study, the use of these instruments is deemed appropriate by the researchers (Babbie, 2004; Sarantakos, 2005). The questionnaire was used to collect data from the respondents other than the key informants. For the first research objective, there were 10 items in all. The items on the factors affecting employee retention were also 10 in all. In both cases, a scale of 1 to 5 was used, with 5 representing strongly agreed (SA) and 1 
representing strongly disagreed (SD). The interview guide was used to collect data from the Registrars. The issues in the interview guide were informed by the items in the questionnaire. The Cronbach alpha coefficients of the questionnaire to research objectives 1 and 2 were calculated and the reliability was determined to be .80 and .70 respectively. These reliability results are in line with the expectations of George and Mallery (2003).

Data generated through the questionnaire was edited to ensure that there were no inconsistencies before coding was done. Collected data were processed using the SPSS version 21.0. The researchers relied on frequencies, percentages and Kruskal-Wallis in analyzing the quantitative data. For the frequencies and percentages, the responses for strongly agreed (SA) and agreed (A) to each statement were merged into agreed for easy appreciation. The same approach was adopted for responses for strongly disagreed (SD) and disagreed (D). Data generated from the interview guide were transcribed verbatim and grouped according to the various themes to satisfy the purpose of the study. As part of research ethics, the purpose of the study was explained to the respondents before the collection of data. Also, participants were assured of confidentiality and anonymity of information provided, and that participation was voluntary. The consent of all respondents was sought before the collection of data.

\section{Results}

The results and discussion section is presented in two parts. Part one concentrates on the background information of the respondents whilst part two looks at the results based on the specific objectives. The background characteristics of respondents were discussed with regard to sex, years of experience and the categories of the staff of the selected institutions. There were about 79 percent of the respondents were males while about 21 percent were females as shown in Table 1. This implies that the workforce of the institutions was dominated by males.

Table 1: Sex Distribution of Respondents

\begin{tabular}{lll}
\hline Sex of Respondents & Frequency & Percentage \\
\hline Male & 88 & 79 \\
Female & 23 & 21 \\
\hline Total & 111 & 100 \\
\hline
\end{tabular}

Source: Field Survey (2018)

The finding on sex distribution is vital because according to Luddy (2005), and Murrary et al. as cited in Danso (2013), sex influences the employees' perception of retention. Murrary et al. further observed that men tend to be influenced by factors such as remuneration, while females tend to perceive higher satisfaction with relationships with co-workers than males.

The study further explored the respondents' total number of years spent with the universities. From Table 2, it is clear that 52.2 percent of the respondents had spent between 1 and 5 years whilst 34.2 percent had spent less than a year with the institution. This means that the majority $(86.4 \%)$ of the respondents had spent between one and 5 years with their institution. This indicates that they had relatively relevant experience in their institutions for goal accomplishment. The importance of experience in tertiary education has been stressed by Gascard, as cited in Kwaw (2015). The author submits that experience of personnel is vital in the efforts of tertiary institutions to improve their staff capacity. Odoom, Kyeremeh and Opoku (2014) subscribe to the argument that employees need some level of experience to be competent in their organizations.

Table 2: Years of Working Experience of Respondents

\begin{tabular}{lll}
\hline Years of experience & Frequency & Percentage \\
\hline less than 1 & 38 & 34.2 \\
$1-5$ & 58 & 52.3 \\
$6-10$ yrs & 10 & 9.0 \\
Above 10 & 5 & 4.5 \\
\hline Total & 111 & 100.0 \\
\hline
\end{tabular}

Source: Field Survey (2018)

Lastly, on the background features, the study looked at the categories of the staff at the institutions. The results are summarized in Table 3. It is clear from Table 3 that while 70.6 percent of the respondents were academic staff whilst 29.4 percent were within the category of non-academic staff. This shows that there were more academic staff members at the institutions than non-academic staff. This situation may be a symptom of the fact that the core mandate of the institutions is teaching and so would employ more teaching staff to help achieve this mandate with seemingly a little focus on the employment of non-academic staff.

Table 3: Categories of Senior Members

\begin{tabular}{lll}
\hline Category of staff & Frequency & Percentage \\
\hline Teaching & 85 & 70.6 \\
Non-Teaching & 26 & 29.4 \\
\hline Total & 111 & 100 \\
\hline
\end{tabular}

Source: Field Survey (2018) 
4.1 Expectations of Senior Members which influenced their decision to work at the selected university colleges

The first research objective sought to explore the expectations Senior Members had which influenced their decision to accept employment in the selected institutions. The results from the questionnaire have been presented in Table 4. Several revelations were made. Most of the Senior Members stated that high salary, better working conditions, more training opportunities, career development opportunities, and a favourable working environment were the expectations that influenced their decision to accept to work at the institutions. Other expectations were increased participation in decision making, challenging tasks, recognition and appreciation, and more prestige in society. From Table 4, it can be seen that 85.6 percent of the respondents generally agreed that they chose to accept to work with the institutions because they had expected to receive salaries higher than they received from their previous institutions. Similarly, 67.7 percent of the respondents stated that they expected better working conditions in their institutions upon assuming office whilst 71.5 percent pointed to more training opportunities than what they had expected to be given to them in the institutions.

Again, 72.5 percent had expected the institutions to offer them opportunities to effectively utilize their talents and skills, with 73.9 percent who had expected a favorable working environment. Besides, the study revealed 63.7 percent of the respondents expected their institutions to enable them to have increased participation in decision making and 60.5 percent taught they were going to be given more challenging tasks in the institutions. Other expectations include more recognition and appreciation $(69.9 \%)$, and more prestige in society $(63.4 \%)$. It is obvious from Table 4 that the most dominant expectation of Senior Members was higher salary.

Table 4: Expectations of Senior Members which influenced their decision to accept to work at the Universities

\begin{tabular}{lcccc}
\hline Expectation- I expected to have/receive: & SA (\%) & A (\%) & D (\%) & SD (\%) \\
\hline Higher salary by joining the institution & 46 & 39.6 & 5.6 & 8.2 \\
Better working conditions & 37.8 & 29.9 & 21.3 & 11 \\
More training opportunities by joining the institution & 39.6 & 31.9 & 21.6 & 6.9 \\
More career development opportunities & 36.6 & 39 & 9.2 & 14.6 \\
Talent and skill utilization & 31.9 & 40.6 & 19.6 & 7.9 \\
Favorable working environment & 42.9 & 31 & 21.9 & 4.2 \\
Increased participation in decision making & 33.8 & 29.9 & 18.9 & 17.4 \\
More challenging tasks & 31.7 & 28.8 & 19.9 & 19.4 \\
More recognition and appreciation & 38.9 & 31 & 18.7 & 11.4 \\
More prestige in society & 29.8 & 33.6 & 22.8 & 13.8 \\
\hline
\end{tabular}

Source: Field Survey (2018)

4.2 Factors which would influence Senior Members' decision to stay in the selected university colleges The second study objective looked at the factors which would influence Senior Members' to stay in their institutions. It could be observed from Table 5 that the majority $(65.4 \%)$ of the respondents indicated generally that communication and information sharing is a key factor that would ensure their retention in the selected institutions. More so, the study found that 61.1 percent of the respondents generally agreed that more training and development opportunities could cause them to stay with their institution while 38.9 percent generally disagreed. This means that many $(61.1 \%)$ of the Senior Members can be retained in the institution provided they have the opportunity for more training and development.

Again, it is clear from the same table that about 62 percent of the Senior Members believed better promotion could cause them to stay with their institution while about 38 percent generally disagreed. By implication, most of the Senior Members believed with better promotion systems in place they are prepared to stay with the institution. In the same vein, most (61.5\%) of the Senior Members were prepared to stay with the institution on the condition that there would be more chances to utilize their talents and skills. 
Table 5: Factors which would influence Senior Members' stay in the institutions

\begin{tabular}{lcccc}
\hline Factor that would influence retention & SA (\%) & A (\%) & D (\%) & SD (\%) \\
\hline Communication and information sharing & 29.6 & 35.8 & 21.6 & 13 \\
Training and career development opportunities & 28.5 & 32.6 & 22.5 & 16.4 \\
Better promotion system & 30.5 & 31.6 & 20.4 & 17 \\
More chances to utilize their talents and skills & 25.9 & 35.6 & 20.5 & 17 \\
Conducive working environment & 34.5 & 29 & 20.5 & 16 \\
Employee engagement & 31.6 & 29.5 & 18.5 & 20.4 \\
More challenging tasks & 28.9 & 27.6 & 19.9 & 23.6 \\
Better remuneration & 46.3 & 31.9 & 10.6 & 11.2 \\
Increased recognition and appreciation & 28.6 & 35.8 & 21.6 & 14 \\
Care and concern for employees & 36.8 & 37.6 & 14.8 & 10.2 \\
\hline
\end{tabular}

Source: Field Survey (2018)

Furthermore, while about 64 percent identified a conducive working environment as what could influence their stay in the institution only 42.9 percent disagreed that increased employee engagement could influence their stay in the institution. Additionally, more than half (61.1\%) of the respondents said employee engagement would influence their retention in the institutions. Other factors affecting include better remuneration (78.2\%), increased recognition and appreciation $(64.4 \%)$, and care and concern for employees $(74.4 \%)$. In fact, of all the factors that can influence Senior Members to stay with the institution, the issue of better remuneration (78.2\%) was found to be the most commanding factor, followed by care and concern for employees $(74.4 \%)$.

\subsection{Differences in the views of Senior Members of the selected institutions about the factors which would influence their retention}

The third and final objective of this study determined the difference between the views of Senior Members of the selected university colleges on the factors which would influence their retention in the institutions. A KruskalWallis test analysis was employed in addressing this objective (Table 6). The significance level $(p=0.689)$ is greater than the alpha value of 0.05 . This shows that there was no statistically significant difference in the views of Senior Members (academic and non-academic staff) of the selected colleges concerning the factors which would influence their retention in the institutions. By implication, the views of (academic and non-academic staff on the factors which would influence their retention were the same regardless of the institutions they belonged. The result also suggests that factors affecting staff retention should be looked at carefully in all the selected university colleges to avoid any negative effects on the institutions. Dibble (1999) opines that the retention of employees needs to be managed effectively in all organizations. The author further identified remuneration, development, career opportunity, work environment, performance management, etc. as vital in employee retention.

Table 6: A Kruskal-Wallis test analysis of Senior Members of the selected university colleges on the factors which would influence their retention in the institutions

\begin{tabular}{crrrcc}
\hline Institution & $\mathrm{N}$ & Mean Rank & $\mathrm{X}^{2}$ & Df & Sig. (2-tailed) \\
\hline CAUC & 14 & 56.18 & 1.432 & 3 & 0.698 \\
UCMS & 12 & 55.00 & & & \\
GCUC & 42 & 49.65 & & & \\
SUC & 39 & 57.59 & & & \\
\hline Total & 107 & & & & \\
\hline
\end{tabular}

(Statistic is significant at 0.05): $\quad d f=$ degree of freedom; $\quad \mathrm{X}^{2}=$ chi-square

Source: Field survey (2018)

\subsection{Findings from the Interviews}

Various findings were made based on the data from the interviews conducted. On the expectations of Senior Members, one Registrar said, "before I came here, I was receiving very little pay from Ghana Education Service, so I expected to receive higher salary by coming to work here (Respondent 1)." Another Registrar bemoaned, "many people are poorly paid here in Ghana. So for many of us when we were coming here we expected to receive a salary higher than our previous employers offered us" (Respondent 2)". Still on Senior Members' before employment, a different Registrar stated, "many employees expect us to pay them high because of what they hear concerning salaries in universities generally but there are peculiar situations across all universities especially private ones (Respondent 3)".

Other expectations from the Registrar who were interviewed include having better working conditions, more training opportunities, career development programs, a favorable working environment, increased participation in decision making, more challenging tasks, increased recognition and appreciation as well as more prestige. One Registrar indicated, "before I assumed office I spoke with a friend in another university who told me that the working condition is far better in some of the private universities, so I was expecting to have a better working 
condition (Respondent 4)." Again, in the words of another Registrar, "almost all Senior Members here also expect that opportunity for training programs and career advancement will be given to them. We also expected to have more challenging tasks and increased recognition (Respondent 3)'”. Thus, the Registrars who constituted the key informants generally stated that increased participation, more appreciation, and a favourable working environment as some of the things most staff members had expected to have before assuming office in the institutions.

On the second objective, a number of issues were observed based on the interview results. Themes that generally emerged include more training and development opportunities, better promotion systems, increased employee engagement, better remuneration, conducive working environment, among others that could influence Senior Members to be retained in the institutions. One of the respondents interviewed said that "better remuneration, training and development opportunities, better promotion systems, increased employee engagement, and conducive working environment largely determine the rate of retention in the university college (Respondent 2)." Additionally, the researchers observed that employee engagement was an important factor affecting retention in the institutions. The Registrars believed that when they are involved in decision making in the organizations, it makes them feel belong and respected in the institutions leading to their willingness to stay. It is an opportunity to bring out important issues to the attention of the management of the universities.

Moreover, a different respondent revealed that employee engagement helped to promote retention "when staff members are involved in key decisions of the school it helps them to think positive of the institution, hence their desire to stay (Respondent 3)". Another informant also commented that "our senior members want to be involved in critical decisions. They think management has to open up and allow them to have a say in the school. But they are also aware that not in all decisions that we can engage them (Respondent 1)." Another Registrar stated, "we are trying our best to engage them but some of them fail to turn up when we call for meetings. How do we involve them if they fail to attend meetings? (Respondent 2)". Other key informants supported the above claim and went ahead to indicate that all senior members need to be ready to attend meetings when they are called.

\section{Discussion}

This section looks at the point of integration concerning the quantitative and qualitative findings in line with the rules of convergent parallel mixed methods design (Plano Clark \& Creswell, 2015). Based on the quantitative data, it was found that respondents had diverse expectations before their engagement by the selected institutions. Their expectations include higher salaries $(85.6 \%)$, better working conditions $(67.7 \%)$, more training and development opportunities $(71.5 \%)$, opportunities to effectively utilize their talents and skills $(72.5 \%)$, a favourable working environment (73.9\%) and increased participation in decision making (63.7\%). Other expectations include challenging tasks in the institutions $(60.5 \%)$, more recognition and appreciation $(69.9 \%)$, and more prestige in society $(63.4 \%)$. Also, interviews with the Registrars generally supported the findings from the questionnaire. For instance, one respondent remarked that "before I came here I was receiving very little pay from Ghana Education Service, so I expected to receive higher salary by coming to work here (Respondent 1)". Another Registrar conceded, "many people are poorly paid here in Ghana. So for many of us when we were coming here we expected to receive a salary higher than our previous employers offered us (Respondent 2)". These results from the interviews largely confirm the issues in the questionnaire as both results suggest that Senior Members had different expectations prior to accepting employment in the selected institutions. It is imperative to note that expectations are the very elements that influence people's decisions to accept to work with organizations although these expectations may sometimes be unrealistic (De Boer et al., 2002). This is since there is a general lack of knowledge among many job applicants about the job at the time that they receive an offer (De Boer et al., 2002). When expectations of an employee are not realized, the worker becomes disappointed and dissatisfied which may force him/her to decide to quit the job (De Boer et al., 2002).

On the factors which would influence Senior Members' retention in the institutions, the data from the questionnaire showed that many factors such as communication and information sharing (65.4\%), training and development opportunities $(61.1 \%)$, better promotion $(62 \%)$, more chances to utilize their talents and skills $(61.5 \%)$, and conducive working environment (64). Other factors revealed through the data obtained using the questionnaire are employee engagement (61.1\%), better remuneration $(78.2 \%)$, increased recognition and appreciation (64.4\%), and care and concern for employees (74.4\%). During the interviews, one Registrar stated, "better remuneration, training and development opportunities, better promotion systems, increased employee engagement, and conducive working environment largely determine the rate of retention in the university college (Respondent 2)." The Registrars generally said that their involvement in decision making in the university colleges make them feel belonged and respected in the institutions. This tends to encourage them to stay with the institutions. One of the Registrar mentioned, "when staff members are involved in key decisions of the school it helps them to think positive of the institution, hence their desire to stay (Respondent 3)." In short, the results from the interviews generally coincide with the quantitative results as both results showed that factors such as more training and development opportunities, better promotion systems, increased employee engagement, better remuneration, conducive working environment, among others could influence Senior Members to stay in the selected University 
Colleges. The findings on retention factors can be compared with what exists in the literature. For example, the finding on communication and information sharing mirrors that of Gopinath and Becker (2000) who contended that communication and information sharing affect employee retention in organizations. The views expressed by Gopinath and Becker (2000) have been supported by Taylor and Cosenza (2002). To make communication effective, Taylor and Cosenza (2002) call for two-way communication which tends to make employees feel comfortable at their workplace. Again, the result on promotion as a key factor of employee retention is similar to previous studies (Odoom, Opoku \& Ayipah, 2016a; Amegatsey, Odoom, Arpoh-Baah \& Okyere, 2018; Odoom, Opoku \& Ayipah, 2016b) which found that promotion is vital in employee retention at the tertiary educational institutions in Ghana. Again, the finding on remuneration coincides with the findings of Amutuhaire (2010) who opined that remuneration influenced employee retention in the institution.

The importance of involving employees in decision making has been stressed by scholars such as Danso (2013), Kampt (2006), and Odoom et al. (2016a). Despite the importance of staff involvement, Odoom et al. (2016a) observed that academic staff members of the Agogo College were not involved in staff development decisions made in the institution. Opportunity for training and development has been identified as very important in the retention of employees (Amegatsey et al., 2018; Jepppesen, 2002; Meyer, Topolnytsky, Krajewski and Gellatly, 2003; Odoom et al., 2014). Jepppesen (2002) further advises organisations to see employee training and development as an investment, rather than a cost, with planning and budgeting requirements similar to those dedicated to capital improvements to strengthen the bond between the organisation and its employees. Again, the findings on the working environment support previous studies (Bultmann et al., 2005; Ramlall, 2004). The authors found that a favourable working environment is one of the factors that affect employees' decision to stay with an organization. Besides, other scholars (Lawler, 2008; Nohria et al., 2008) support a challenging and creative work environment to ensure that employees enjoy the work they do and to avoid micro-managing which impedes creativity. The findings of this study generally provide practical relevance to the Two-Factor Theory since the study identifies intrinsic and extrinsic factors as vital in the retention of employees in any organization (Chiboiwa, Samuel \& Chipunza, 2010).

\section{Conclusions and Recommendations}

Several conclusions were drawn based on the findings of the study. First, the expectations of Senior Members including getting a high salary, better working conditions, more training opportunities, career development opportunities, a favourable working environment as well as obtaining some form of recognition and appreciation influenced their decision to accept to work at the institutions. Second, retention of Senior Members in the institutions could be influenced by factors such as better remuneration, care and concern from employers, more training and development opportunities, a better promotion system, a conducive working environment, and increased employee engagement. However, no significant differences manifest in the views of Senior Members (academic and non-academic staff) of the selected institutions on the factors which influence employee retention. The management of the selected universities should effectively collaborate with their HR Units to put in place measures to ensure that applicants with unrealistic expectations are identified during recruitment and selection exercises to avoid undue pressure from such persons upon employment. The human resource (HR) Units of the selected universities should effectively collaborate with the HRM experts of the universities to design fair and proper training and development programs to motivate employees to stay in the organizations. This could be done by first conducting a needs assessment and also by tailoring training and development programs to suit the career development goals of both teaching and non-teaching senior staff. The managements should team up with the HR Units to properly provide a clear and competitive link between senior members' upgrading and promotion. This will help to enhance retention among both teaching and non-teaching senior staff of the university. The study also recommends that management of the universities should conduct a periodic appraisal on the factors which influence retention and put in place measures to address them to enhance senior members' satisfaction in their institutions. This will help instil confidence and enhance the retention of Senior Members in the institutions. Despite the importance of these findings, the researchers believe that the sample size (111) is relatively small which can affect the generalizability of the results to larger populations. Likewise, the use of the convenience sampling method did not allow for a more probabilistic design which could help researchers to thoroughly address the quantitative aspect of the study.

\section{References}

Al-Omari, A. A., Qablan, A.M., \& Khasawnneh, S. M. (2009). Faculty members intention to stay in Jordanian PublicUniversities. International Journal of Applied Educational Studies, 1(1), 26-42.

Amegatsey, S. (2017). Examining the human resource challenges facing Takoradi Technical University in recruitment, professional development and retention of the academic staff. Unpublished Mphil thesis, University of Cape Coast, Cape Coast.

Amegatsey, S. K., Odoom, D., Bernard Arpoh-Baah \& Isaac Okyere (2018). Exploring the Staff Development and 
Retention Challenges faced by Tertiary Educational Institutions in Ghana: The Case of Takoradi Technical University. European Journal of Business and Management, 10(36), 108-123.

Amutuhaire, T. (2010). Terms of service and job retention among academic staff in Makerere University. Master of Arts in Higher Education Studies Thesis, Makerere University, Kampala.

Armstrong, M. (2007). Handbook of human resource management practice (10 $0^{\text {th }}$ ed.). London: Kogan Page.

Babbie, E. (2004). The practice of social science research $\left(12^{\text {th }}\right.$ ed.). Wadsworth: Cengage Learning Inc.

Bamberger, P., \& Meshoulam, I. (2000). Human resource strategy. Cambridge: Sage Publications.

Beauregard, M., \& Fitzgerald, M. (2000). Hiring, managing and keeping the best: The complete Canadian guide for employers. Journal of Cooperative Education and Internship, 36(1), 48-60.

Beck, R. C. (2003). Motivation: Theories and principles ( $5^{\text {th }}$ ed.). New Jersey: Prentice Hall.

Bultmann, U., Huibers, M. J., van Amelsvoort, L. P., Kant, I., Kasl, S. V., \& Swaen, G. M. (2005). Psychological distress, fatigue and long-term sickness absence: Prospective results from the Maastricht cohort study. Journal of Occupational Environmental Medium, 47(9), 941-947.

Chang, E. (2005). Employees' overall perception of HRM effectiveness. Human Relations, 58, 523-544.

Chiboiwa, M. W., Samuel, M. O., \& Chipunza, C. (2010). An examination of employee retention strategy in a private organisation in Zimbabwe. African Journal of Business Management, 4(10), 2103-2109.

Danso, O. A. (2013). Human resource management practices and senior staff retention at the University of Cape Coast. Unpublished MBA Thesis, University of Cape Coast, Cape Coast.

De Boer, E. M., Bakker, A., B., Syroit, J. E., \& Schaufeli, W. B. (2002). Unfairness at work as a predictor of absenteeism. Journal of Organisational Behaviour, 23, 181-197.

Dibble, S. (1999). Keeping your valuable employees. New York: John Wiley and Sons.

Dhanpat, N., Manakana, T., Mbacaza, J., Mokone, D., and Mtongana, B. (2018). Exploring retention factors and job

security of nurses in Gauteng public hospitals in South Africa. African Journal of Economic and Management Studies, 10(1), 57-71.

Dovlo, D. (2002). Retention and deployment of health workers and professionals in Africa. Consultative meeting on collaboration between health professions and governments in policy formulation and implementation of health sector reform. Addis Ababa, Ethiopia, January 28 - February 1, 2002.

Gascard, G. (2012). Human resource management in public higher education in the Tempus Partner Countries. Retrieved June 27, 2013, from http://eacea.ec.europa.eu/tempus

George, C. (2015). Retaining professional workers: what makes them stay? Employee Relations, 37(1), $102-121$.

George, D., \& Mallery, P. (2003). SPSS for Windows step by step: A simple guide and reference (4th ed.). Boston: Allyn \& Bacon.

Gopinath, C., \& Becker, T. (2000). Communication procedural justice and employee attitudes: relationships under conditions of divestiture. Journal of Management, 26(1), 63-80.

Guest, D. E., Michie, J., Conway, N., \& Sheenan, M. (2003). Human resource management and corporate performance in the United Kingdom. British Journal of Industrial Relations, 41(2), 291-314.

Guthrie, J. (2001). High-involvement work practices, turnover and productivity: Evidence from New Zealand. Academy of Management Journal, 44, 180-192.

Herzberg, F., Mausner, B., \& Snyderman, B. B. (1959). The motivation to work (2 ${ }^{\text {nd }}$ ed.). New York: John Wiley and Sons.

Hughes, J. C. and Rog, E. (2008). Talent management a strategy to improving employee retention,

recruitment and engagement. International Journal of Contemporary Hospitality Management, 20(7), 743-757.

Kampt, C. V. M. (2006). Skills in the global village: Let's make sure South Africa grows and keep its talents. Retrieved from www.hrfuture.net on Thursday, August 4, 2011 at 10:35a.m.

Kraimer, M. L., Seibert, S. E., Wayne, S. J., Liden, R.C. and Bravo, J. (2011). Antecedents and outcomes of organizational support for development: The critical role of career opportunities. Journal of Applied Psychology, 96(3), 485-500.

Kwaw, J. (2015). Staff perception on human resource management challenges and strategies at the Cape Coast Polytechnic. An unpublished master's thesis, University of Cape Coast, Cape Coast.

Lawler, E. E. (2008). Talent: Making people your competitive advantage. San Francisco: Jossey-Bass.

Levi, L. (2002). Guidance on work-related stress: Spice of life, or kiss of death? Luxembourg: Office for Official Publications of the European Communities.

Lockwood, N. R. (2006). Talent management: Driver for organisational success. Alexandria: Society for Human Resource Management.

Luddy, N. (2005). Job satisfaction amongst employees at a Public Health Institution in the Western Cape. Minithesis submitted in partial fulfilment of the requirements for the degree of Master of Commerce in the Department of Industrial Psychology, Faculty of Economics and Management Science, University of the Western Cape. 
Machin, S., \& Oswald, A., (1999). Signs of Disintegration: A Report on UK Economics PhDs and ESRC Studentship Demand, Report to ESRC

Machin, S., \& Oswald, A., (2000). UK Economics and the Future Supply of Academic Economists, Economic Journal, 440, 334-49.

Mahmud, K., \& Idrish, S. (2011). The impact of human resource management practices on turnover of bank employees in Bangladesh. World Review Business Research, 1(2), 71-83.

Malikarjunan, K. (2006). Best of human resource practices. Human Resource Management Review, 6(2), 33-34.

Mandviwala, M. (2011). Promoting without a raise: A recipe of retention or departure. Retrieved from http://www.hrutilities.com/2011/08/ promoting-without-a-raise-a-recipe-of-retention-or-departure/ on Thursday, August 4, 2011 at 9:30a.m.

Mausner, B., \& Snyderman, B. B. (1959). The motivation to work. New York: John Wiley \& Sons.

Mercer Report. (2003). Mercer study raises red flags for employer pay and benefit plans. Human Resource Department Management Report, 8-15.

Meyer, J., Topolnytsky, L., Krajewski, H., \& Gellatly, I. (2003). Best practices: Employee retention. Toronto: Tomson-Carswell.

Miller, N. G., Erickson, A., \&Yust, B. L. (2001). Sense of place: The relationship between personal objects and job satisfaction and motivation. Journal of Interior Design, 27(1), 35-43.

Muah, P., Nyarko Adu, I. ., Kyei-Frimpong, M. ., \& Boakye, A. O. (2021). Explaining How Management Safety Practices and Safety Programs Influence Job Safety and Employee Commitment: Evidence from the Ghanaian Mining Industry. SEISENSE Business Review, 1(3), 41-56. https://doi.org/10.33215/sbr.v1i3.709

Naidoo N. (2000). South Africa is losing hundreds of nurses each year. Retrieved from http://pdf.usaid.gov/pdf_docs/PNADI165.pdf on Tuesday, August 2, 2011

Nohria, N., Groysberg, B., \& Lee, L.(2008). Employee motivation: A powerful new model. Harvard Business Review, 86(7/8), 78-84

Odoom, D., Kyeremeh, C. \& Opoku, E. (2014). Human resource capacity needs at the District

Assemblies: A study at Assin South District in Ghana. Journal of Sustainable Development, 7(5), 177-188.

Odoom, D., Opoku, E. \& Ayipah-Ntiakoh, D. (2016a). Staff development needs at the Colleges of Education in Ghana: Evidence from the Agogo College. International Journal of Innovative Research and Development, 5(1), 127-137.

Odoom, D., Opoku, E. \& Ayipah-Ntiakoh, D. (2016b). Teacher motivation and performance: The case of some selected Early Childhood Care and Education Centres in the Cape Coast Metropolis of Ghana. International Journal of Innovative Research and Development, 5(1), 127-137.

Osei Boakye, A., Dei Mensah, R., Bartrop-Sackey, M., \& Muah, P. (2021). Juggling between work, studies and motherhood: The role of social support systems for the attainment of work-life balance. SA Journal of Human Resource Management, 1910 pages. doi:https://doi.org/10.4102/sajhrm.v19i0.1546

Plano Clark, V. L., \& Creswell, J. W. (2015). Understanding research: A consumer's guide (2 ${ }^{\text {nd }}$ ed.). New Jersey: Pearson Education Inc

Ramlall, S. (2004). A review of employee motivation theories and their implications for employee retention within organisations. Journal of American Academy and Business, 52(8), 52-63.

Robyn, A. M. (2012). Intention to quit amongst generation Y academics at higher education institutions. MCom thesis. Stellenbosch: Stellenbosch University.

Robbins, S. P., Odendaal, A., \& Rood, G. (2007). Organisational behaviour: Global and Southern African perspective. ( $9^{\text {th }}$ ed.). Cape Town: Pearson Education.

Samuel, M. O., \& Chipunza, C. (2009). Employee retention and turnover: Using motivational variables as a panacea. African Journal of Business Management, 3(8), 410-415.

Sarantakos, S. (2005). Social research. New York: Palgrave Macmillan.

Silbert, L. T. (2005). The effect of tangible rewards on perceived organisational support management. Retrieved from uwspace.uwaterloo.ca/bitstream/10012/872/1/1silbert2005.pdf on Tuesday, August 2, 2011 at 9:00a.m.

Smith, G. P. (2001). Here today, here tomorrow: Transforming your workforce from high turnover to high retention. New York: Dearborn Financial Publishing Inc.

Taher, A., \& Arifen, K. (2000). Recruitment and selection process in human resource management. New Delhi: Gandhi University Press.

Taylor, S., \& Cosenza, R. (2002). Profiling later aged female teens: Mall shopping behaviour and clothing choice. Journal of Consumer Marketing, 19(5), 393-408.

Tymon, W. G., Stumpf, S. A., and Smith, R. R. (2011). Manager support predicts turnover of professionals in India. Career Development International 16(3), 293-312.

Vinesh, A. (2014). Role of training and development in an organizational development. International Journal of Management and International Business Studies, 4(2), 213-220.

Whitchurch, C. (2006a). Who do they think they are? The changing identities of professional administrators and 
managers in UK higher education. Journal of Higher Education Policy and Management, 29 (2), 159-171.

Whitchurch, C., \& Gordon, G. (2007). Managing human resources in higher education: The implications of a diversifying workforce. Higher Education Management and Policy Journal, 19 (2), 135-155.

Whitener, E. M. (2001). Do high commitment human resource practices affect employee commitment? A crosslevel analysis using hierarchical linear modelling. Journal of Management, 27(5), 515-64. 